\title{
EFFICACY OF HERBICIDES ON THE SOIL MICROFLORA DURING THE CROP GROWTH OF TRANSPLANTED RICE
}

\section{P. SPANDANA BHATT, M. YAKADRI, M. MADHAVI, S. SRIDEVI \& P. LEELA RANI}

Department of Agronomy, Pjtsa University, Hyderabad, Telangana, India

\begin{abstract}
The use of herbicides in transplanted rice may affect the biological equilibrium of the soil and thus influence the nutrient status, health and productivity of the soil. To study the effect of herbicides on soil microbial populations of transplanted rice, field experiment was conducted at PJTSAU, Hyderabad during Kharif 2013 and 2014. Fourteen weed control treatments, viz. $T_{1}$ : pretilachlor@625 ga.i. ha $a^{-1}$ as PE at 3 DAT, $T_{2}$ : pyrazosulfuron ethyl @ $20 \mathrm{~g}$ a.i.ha-1 3 DAT, $T_{3}:$ pretilachlor 6\% + bensulfuron methyl 0.6\% @ $10 \mathrm{~kg}$ granules ha ${ }^{-1}$ as PE at 3 DAT, T4: pyrazosulfuron ethyl @ $20 \mathrm{~g}$ a.i. ha $\mathrm{a}^{-1}$ at 3 DAT followed by manual weeding at 25 DAT, $T_{5}$ : penoxsulam @ $22.5 \mathrm{~g}$ a.i. Ha - $^{-1}$ as Poe at 12 DAT, T6: cyhalofop-p-butyl @ $100 \mathrm{~g}$ a.i. $\mathrm{Ha}^{-1}$ as Poe 15 DAT, T7: bispyribac sodium @ $25 \mathrm{~g}$ a.i. ha $\mathrm{T}^{-1}$ as PoE 25 DAT, T azimsulfuron@ $35 \mathrm{~g}$ a.i. ha $\mathrm{a}^{-1}$ as PoE at 25 DAT, $\mathrm{T}_{9}$ : bispyribac sodium @ $25 \mathrm{~g}$ a.i. ha $\mathrm{a}^{-1}+$ ethoxy sulfuron $18.75 \mathrm{~g}$ a.i. ha $\mathrm{a}^{-1}$ as PoE at 25 DAT, T10:bispyribac sodium @ $20 \mathrm{~g}$ a.i. ha ${ }^{-1}+$ metsulfuron methyl + chlorimuron ethyl @ $4 \mathrm{~g}$ a.i. ha $\mathrm{a}^{-1}$ as PoE at 25 DAT, T11: pretilachlor@ $750 \mathrm{~g}$ a.i. ha $a^{-1}$ as PE at 3 DAT fb ethoxy sulfuron @ $18.75 \mathrm{~g}$ a.i. ha $a^{-1}$ as PoE at 25 DAT, T12: pretilachlor @ $750 \mathrm{~g}$ a.i. ha $a^{-1}$ as PE at 3 DAT fb metsulfuron methyl + chlorimuron ethyl @ $4 \mathrm{~g}$ a.i. ha $a^{-1}$ as PoE at 25 $D A T, T_{13}$ : hand weeding twice at 25 and $45 \mathrm{DAT}$ and $T_{14}$ : weedy check. The results revealed that microorganisms are able to degrade herbicides and utilize them as a source of biogenic elements for their own physiological processes. However, before degradation, herbicides have toxic effects on microorganisms, reducing their abundance, activity and consequently, the diversity of their communities. The toxic effects of herbicides are normally most severe immediately after application. Later on, microorganisms take part in a degradation process, and then the degraded organic herbicides provide carbon rich substrates which in terms maximize the microbial population in the rhizosphere.

KEYWORDS: Actinobacteria, Bacteria, Transplanted Rice, Fungi, Herbicides \& Non-Target Organisms
\end{abstract}

Received: Apr 12, 2017; Accepted: Apr 28, 2017; Published: May 08, 2017; Paper Id.: IJASRJUN201720

\section{INTRODUCTION}

Herbicide technology offers an alternative method of selective and economical control of weeds right from the beginning, giving crop an advantage of a good start and competitive superiority. Herbicides not only save time and money but also allow coverage of more area in a short period of time (Nyarko and Datta, 1991). The development of herbicides for weed control was a fascinating success story during the last decade, generally, most herbicides are effective for selective weed control and a single herbicide cannot control all weeds of the community (Corbelt et al., 2004). Combination products consisting of two or more herbicides have greater activity on diverse weed flora due to differential mode of action and have become popular in recent years.

Due to severity of weed problem and lack of knowledge about the residual effect of herbicides there is a tendency for indiscriminate use of herbicides in rice fields. Such continuous and intensive use of herbicides year after year poses a problem of herbicide resistance and consequently, management of weeds is becoming increasingly more difficult and complex (Rao, 2000). Moreover the continuous use of these herbicides leads to a 
shift of weed flora from grassy to non grassy broadleaf weeds and annual sedges, build up herbicide resistance, health hazards and ground water contamination.

Hence the focus at present is on new molecules with low dose and high efficacy in the field conditions. Keeping in view the above facts, there is a need to reduce the evolution of herbicide resistance in weeds and the shift towards problematic weeds by avoiding the continuous use of a single herbicide or herbicides with similar mechanism of action. An assessment of the performance of different herbicides, which can provide wide weed control spectrum in transplanted rice will be useful for evolving an economically viable and environmentally safe weed management strategy for transplanting rice.

Herbicides are biologically active compounds, and an unintended consequence of its application may lead to significant changes in microbial populations and activities influencing microbial ecological balance affecting soil fertility. The fate of herbicides applied in agricultural ecosystems is governed by the transfer and degradation processes, and their interaction with soil microorganisms. The sustainable agriculture involves optimizing agricultural resources and at the same time maintaining the quality of the environment and sustaining natural resources. In achieving this optimization, the soil microbial community composition is of great importance, because they play a crucial role in carbon flow, nutrient cycling and litter decomposition, which in turn affect soil fertility and plant growth. The increasing reliance of sustainable agriculture on herbicides has led to a concern about their ecotoxicological effects influencing microbial populations and enzyme activities, which may serve as indicators of soil quality. The interaction between herbicides and soil microorganisms may be of practical significance because of possible inhibition in microbial activities contributing to soil fertility. Hence there is a need to study the effects of herbicides on soil microbial population communities, thereby addressing the apprehensions about the environmental impacts of herbicide use.

\section{MATERIALS AND METHODS}

The investigation was carried out during kharif 2013 and 2014 at college farm, Professor Jayashankar State Agricultural university, Rajendranagar, Hyderabad, situated at an altitude of $542.3 \mathrm{~m}$ above MSL at $17^{\circ} 19^{\prime} \mathrm{N}$ latitude and $78^{\circ} 23^{\prime}$ E longitude. It is in the Southern Telangana agro-climatic zone of Telangana state. According to the Troll's climatic classification, it falls under semi-arid tropics (SAT).

The meteorological data recorded during the rice growing season showed that Mean weekly maximum temperatures ranged from $25.3^{\circ} \mathrm{C}$ to $31.5^{\circ} \mathrm{C}$ and $27.5^{\circ} \mathrm{C}$ to $34.0^{\circ} \mathrm{C}$, while mean weekly minimum temperatures varied from $11.4{ }^{\circ} \mathrm{C}$ to $25.0{ }^{\circ} \mathrm{C}$ and $16.1{ }^{\circ} \mathrm{C}$ to $24.5^{\circ} \mathrm{C}$ during $2013-14$ and $2014-15$, respectively. The mean morning relative humidity RH (I) during the crop growing period varied from 84 to $92 \%$ and 76 to $93 \%$, while mean weekly afternoon relative humidity RH (II) 37 to $91 \%$ and 24 to $81 \%$ during 2013-14 and 2014-15, respectively. The weekly mean sunshine hours fluctuated between 0.3 hours to 8.1 hours and 1.0 to 8.3 . The average wind speed varied from 1.1 to $13.2 \mathrm{~km} \mathrm{~h}^{-1}$ in $2013-14$ and 1.8 to $14.5 \mathrm{~km} \mathrm{~h}^{-1}$ in 2014-15. With respect to pan evaporation, mean pan evaporation ranged from 1.5 to $5.1 \mathrm{~mm} \mathrm{day}^{-1}$ and 1.4 to $5.6 \mathrm{~mm} \mathrm{day}^{-1}$ in 2013-14 and 2014-15, respectively. During the cropping period rainfall of $601.1 \mathrm{~mm}$ was received in 36 rainy days and $362.3 \mathrm{~mm}$ received in 35 rainy days in 2013-14 and 2014-15, respectively. The soil of the experimental site was sandy clay loam in texture with normal soil reaction and electrical conductivity, low in organic carbon and available $\mathrm{N}$ and medium in available $\mathrm{P}$ and $\mathrm{K}$. The experiment comprised of 14 weed control treatments, viz. $\mathrm{T}_{1}$ : pretilachlor @ $625 \mathrm{~g}$ a.i. $\mathrm{ha}^{-1}$ as PE at 3 DAT, $\mathrm{T}_{2}$ : pyrazosulfuron ethyl @ 20 g a.i. ha ${ }^{-1} 3$ DAT, $\mathrm{T}_{3}$ : pretilachlor $6 \%+$ bensulfuron methyl 0.6\%@10 kg granules ha ${ }^{-1}$ as PE at 3 DAT, T ${ }_{4}$ : pyrazosulfuron ethyl @ $20 \mathrm{~g}$ a.i. ha ${ }^{-1}$ at 3 DAT 
followed by manual weeding at 25 DAT, $\mathrm{T}_{5}$ : penoxsulam @ $22.5 \mathrm{~g}$ a.i. ha ${ }^{-1}$ as PoE at 12 DAT, $\mathrm{T}_{6}$ : cyhalofop-p-butyl @ $100 \mathrm{~g}$ a.i. $\mathrm{ha}^{-1}$ as PoE 15 DAT, $\mathrm{T}_{7}$ : bispyribac sodium @ $25 \mathrm{~g}$ a.i. ha ${ }^{-1}$ as PoE 25 DAT, $\mathrm{T}_{8}$ : azimsulfuron @ $35 \mathrm{~g}$ a.i. ha ${ }^{-1}$ as PoE at 25 DAT, $\mathrm{T}_{9}$ : bispyribac sodium @ $25 \mathrm{~g}$ a.i. ha ${ }^{-1}+$ ethoxy sulfuron $18.75 \mathrm{~g}$ a.i. ha ${ }^{-1}$ as PoE at $25 \mathrm{DAT}, \mathrm{T}_{10}$ :bispyribac sodium @ $20 \mathrm{~g}$ a.i. ha ${ }^{-1}+$ metsulfuron methyl + chlorimuron ethyl @ $4 \mathrm{~g}$ a.i. ha ${ }^{-1}$ as PoE at $25 \mathrm{DAT}, \mathrm{T}_{11}$ : pretilachlor @ $750 \mathrm{~g}$ a.i. ha ${ }^{-1}$ as PE at 3 DAT fb ethoxy sulfuron @ $18.75 \mathrm{~g}$ a.i. ha ${ }^{-1}$ as PoE at 25 DAT, $\mathrm{T}_{12}$ : pretilachlor @ $750 \mathrm{~g}$ a.i. ha ${ }^{-1}$ as PE at 3 DAT fb metsulfuron methyl + chlorimuron ethyl @ $4 \mathrm{~g}$ a.i. ha ${ }^{-1}$ as PoE at 25 DAT, $\mathrm{T}_{13}$ : hand weeding twice at 25 and 45 DAT and $\mathrm{T}_{14}$ : weedy check. In laid out in randomized block design and replicated thrice. Rice variety 'MTU 1010' was seeded on 8 th august 2013 and 4th august 2014 in rows spaced at $20 \mathrm{~cm}$. The recommended dose of fertilizers and plant protection measures for insect-pest and disease control were applied. Enumeration of the soil microbial population was carried out just before the spraying the herbicide and at 3,20 days after herbicide application, i.e. 6 DAT, 12 DAT, 15 DAT, 23 DAT, 25 DAT, 28 DAT, 32 DAT, 45 DAT and at 60 DAT. Total count of fungi, bacteria and actinomycetes was assessed by serial dilution plate technique (Johnen and Drew1977.). One gram of soil was added to 100 $\mathrm{ml}$ of sterilized distilled water in a $250 \mathrm{ml}$ conical flask under aseptic condition and shaken for 30 minutes in a orbital shaker for uniform mixing for obtaining $10^{-2}$ dilution. With a sterile pipette, $1 \mathrm{ml}$ of $10^{-2}$ dilution was transferred to $9 \mathrm{ml}$ sterile water blank and mixed well to obtain a $10^{-3}$ dilution. Father in the same way to obatain $10^{-4}, 10^{-5}$ and $10^{-6}$ dilution. One $\mathrm{ml}$ aliquots of required dilutions were separately transferred to sterile petri dishes for enumeration of bacteria, fungi and actinomycetes. Similarly, one $\mathrm{ml}$ aliquot of $10^{-6}$ dilution was transferred to sterile petri dishes for enumeration. Melted and cooled nutrient agar, potato dextrose agar and actinomycetes agar media were poured into petri dishes @ $10 \mathrm{ml}$ per dish for the estimation of bacteria, fungi and actinomycetes respectively. Plates were incubated at $28^{\circ} \mathrm{C}$. Observations were taken to the colonies after 24 hours in the case of bacteria, 72 hours for fungi and 154 hours for actinomycetes. The colonies were counted and the number of viable bacteria, fungi and actinobacteria [expressed as colony forming units (cfu)] per gram dry weight of soil was estimated by taking into account the soil dilutions.

\section{RESULTS AND DISCUSSIONS}

\section{Bacterial Population}

A perusal of data on the bacterial population furnished in Table 1 and 2 revealed that there was a significant difference among the treatments over varying time intervals in a crop season during both the years.

There was an increase in the population of soil bacteria in the hand weeded and weedy check plots throughout the crop growing season from 0 DAT to 45 DAT and then at 60 DAT the increase in bacterial population was insignificant. During the herbicide treatments, population of soil bacteria was lower after spraying. Maximum reduction was noticed at 3 days after herbicide application in both the crop seasons.

Treatments where the PE herbicide application was done with two chemical group containing chloro acetamide in (pretilachlor in $\mathrm{T}_{1}, \mathrm{~T}_{11}$ and $\mathrm{T}_{12}$ ), $\mathrm{T}_{3}$ pretilachlor $6 \%$ + bensulfuron methyl $0.6 \%$ @ $10 \mathrm{~kg}$ granules ha ${ }^{-1}$ as PE at $3 \mathrm{DAT}$ and sulfonyl urea $\left(\mathrm{T}_{2}\right.$ and $\mathrm{T}_{4}$ pyrazosulfuron ethyl @ $20 \mathrm{~g}$ a.i. $\left.\mathrm{Ha}^{-1}\right)$ the reduction in bacterial population in the range of $23 \%$ to $30 \%$ and $29 \%$ to 34\% over control during 2013 and 2014 respectively. In later stages the bacterial population increased and recorded on par results with control as crop reached 23 DAT. They're after above said treatments (T1, T2, T3, and T4) recorded higher bacterial population than control during both the years. At 12 DAT early PoE herbicide application of penoxsulam @ $22.5 \mathrm{~g}$ a.i. ha ${ }^{-1}\left(\mathrm{~T}_{5}\right)$, cyhalofop-p-butyl @ $100 \mathrm{~g}$ a.i. $\mathrm{Ha}^{-1}\left(\mathrm{~T}_{6}\right)$ showed a sharp decrease in bacterial population 3 days after herbicide application (15 DAT) and then it showed increasing trend and recorded on par results 
with control by 28 DAT during 2013 and by 35 DAT during 2014.

At 25 DAT PoE treatments imposition with sulfonyl urea group herbicides azimsulfuron $\left(\mathrm{T}_{8}\right)$, ethoxysulfuron $\left(\mathrm{T}_{9}\right.$ and $\left.\mathrm{T}_{11}\right)$, metsulfuron methyl + chlorimuron ethyl $\left(\mathrm{T}_{10}\right.$ and $\left.\mathrm{T}_{12}\right)$ and pyramidinethio benzoate group of herbicide bispyribac sodium $\left(\mathrm{T}_{7}, \mathrm{~T}_{9}\right.$ and $\left.\mathrm{T}_{10}\right)$ was done. Both the group showed decreases in bacterial population from 3 days after herbicide application (28 DAT) and then significantly increased in later stages by 45 and 60 DAT during both the years.

The bacterial population was affected by herbicide application only during the initial stages. Amongst herbicide treatments the higher reduction in bacteria observed in $\mathrm{T}_{11}$ and $\mathrm{T}_{12}$ where sequential application of herbicide was done. It could be further inferred that the bacterial population started to regain after the weeds were also killed by the herbicides and got mixed in the soil and these might have served to increase the nutrients. The degradation of herbicides may be serving as a carbon source for growth of microbes. These results were in tune with finding of Jarvan et al. (2014). The bacterial population in herbicide treated plots was more or less similar to the unsprayed control plots in later stages indicating that herbicides have no detrimental effect on soil health at applied doses. Anderson (2003) reported that herbicides generally appear to have no adverse effect on total bacterial population in soil except at concentrations exceeding recommended rates.

\section{Fungal Population}

The dynamics of the fungal population consequent to the application of herbicides were monitored by conducting soil plate dilution study of soil samples taken from the treatment plots at different intervals (Table 3 and 4 ) and found vary significantly.

The results revealed that the population of fungi in the soil was not uniform during the entire crop period in the control plot also. Maximum reduction in the population of fungi was observed at 3 days after herbicide application i.e., 6 DAT, 15 DAT and 28 DAT in PE herbicide applied plots (pretilachlor in $T_{1}, T_{3}, T_{11}$ and $T_{12}$, pyrazosulfuron ethyl in $T_{2}$ and $\mathrm{T}_{4}$ ), early PoE applied plots (penoxsulam in $\mathrm{T}_{5}$, cyhalofop-p-butyl in $\mathrm{T}_{6}$ ) and PoE herbicide plots (azimsulfuron $\mathrm{T}_{8}$, ethoxysulfuron $\left(\mathrm{T}_{9}\right.$ and $\left.\mathrm{T}_{11}\right)$, metsulfuron methyl + chlorimuron ethyl $\left(\mathrm{T}_{10}\right.$ and $\left.\mathrm{T}_{12}\right)$ and pyramidinethio benzoate group (bispyribac sodium in $\mathrm{T}_{7}, \mathrm{~T}_{9}$ and $\mathrm{T}_{10}$ ) respectively. The percentage of reduction in fungal population was $29.6 \%, 38.4 \%$ and $29.4 \%$ in 2013, 28.9\%, 37.6\% and 33.9\% during 2014 in pre, early post and PoE herbicide plots respectively. The significantly higher reduction was observed in sequential herbicide applied plots $\left(\mathrm{T}_{11}\right.$ and $\left.\mathrm{T}_{12}\right)$ during both the years of study.

Roberts (1998) concluded that microbial activities were more sensitive to herbicides leading to slight initial suppressing effect, degradation of herbicides in rice fields was augmented by high temperatures which usually stabilize in range favouring high microbial activity. After initial reduction, fungi population found to increase and recorded on par results with unsprayed plots (hand weeding and weedy check) by 23 DAT in PE herbicide treated plots $\left(\mathrm{T}_{1}, \mathrm{~T}_{2}, \mathrm{~T}_{3}, \mathrm{~T}_{4}, \mathrm{~T}_{11}\right.$ and $\left.\mathrm{T}_{12}\right), 35$ DAT in early PoE herbicide treated plots $\left(\mathrm{T}_{5}\right.$ and $\left.\mathrm{T}_{6}\right)$ and by 60 DAT in PoE herbicide treated plots $\left(\mathrm{T}_{7}, \mathrm{~T}_{8}, \mathrm{~T}_{9}, \mathrm{~T}_{10}, \mathrm{~T}_{11}\right.$ and $\left.\mathrm{T}_{12}\right)$ during both the years.

The initial decrease followed by small increase in population could also be due to microbial multiplication on the increased supply of nutrients available in the form of microorganisms killed by herbicides (Bowels et al., 2014).

Thus all herbicides exhibited detrimental influence on soil fungal population up to 20 days after herbicide application which was recovered later on. These results are in concurrent with Chauhan et al. (2006). 


\section{Actinomycetes Population}

A perusal of data on actinomycetes population furnished in Table 4.36 and 4.37 revealed that there was significant difference among the treatments over varying time intervals in a crop season during both the years.

The results revealed that the reduction in the population of actinomycetes was observed at 3 days after herbicide application i.e., 6 DAT, 15 DAT and 28 DAT in PE herbicide applied plots (pretilachlor in $\mathrm{T}_{1}, \mathrm{~T}_{3}, \mathrm{~T}_{11}$ and $\mathrm{T}_{12}$ and pyrazosulfuron ethyl in $\mathrm{T}_{2}$ and $\mathrm{T}_{4}$ ), early PoE applied plots (penoxsulam in $\mathrm{T}_{5}$, cyhalofop-p-butyl in $\mathrm{T}_{6}$ ) and PoE herbicide plots (azimsulfuron $T_{8}$ ), ethoxysulfuron $\left(T_{9}\right.$ and $\left.T_{11}\right)$, metsulfuron methyl + chlorimuron ethyl $\left(T_{10}\right.$ and $\left.T_{12}\right)$ and (bispyribac sodium in $\mathrm{T}_{7}, \mathrm{~T}_{9}$ and $\mathrm{T}_{10}$ ) respectively. However reduction in actinomycetes population was less compared to bacterial and fungal population.

The herbicides treatment effects on soil actinomycetes population growth exhibited short term rapid decreasing trends at initial days, and the effects were zero at 15 days after application which indicate full recovery of the actinomycetes populations from the initial herbicidal effects. This was to be expected because the amounts of herbicides molecules present in the soil were negligible to have any influence on actinomycetes population that ultimately lead to zero inhibition of actinomycetes growth. The decrease in the population of total actinomycetes was due to competitive influence and the toxic effect as well as different persistence periods of the treated herbicides. In addition, the increase in population at later stages was affected by the proto-cooperative influence of various microorganisms on total actinomycetes in the rhizosphere. For all the cases of herbicidal treatments, total actinomycetes recovered from initial loss and exceeded the initial counts (Ghosh et al., 2012).

Bera and Ghosh (2013) reported that microorganisms are able to degrade herbicides and utilize them as a source of biogenic elements for their own physiological processes. However, before degradation, herbicides have toxic effects on microorganisms, reducing their abundance, activity and consequently, the diversity of their communities. The toxic effects of herbicides are normally most severe immediately after application. Later on, microorganisms take part in a degradation process, and then the degraded organic herbicides provide carbon rich substrates which in terms maximize the microbial population in the rhizosphere.

From the investigation it was concluded that there was an increase in the population of soil bacteria, fungi and actinomycetes in the hand weeded and weedy check plots. In the herbicide treatments, population of soil bacteria, fungi and actinomycetes was lower immediately after spraying. Maximum reduction was noticed at 3 days after herbicide application in both the crop seasons.

The reduction in bacteria population was in the range of $23 \%$ and 30\% over control during 2013 and 2014 respectively.

The percentage of reduction in fungal population was $29.6 \%, 38.4 \%$ and $29.4 \%$ in $2013,28.9 \%, 37.6 \%$ and $33.9 \%$ during kharif 2014 in pre, early post and post emergence herbicide plots respectively. Significantly higher reduction was observed in sequential herbicide applied plots than sole application of herbicides.

The reduction in actinomycetes population due to herbicide application was less compared to bacteria and fungi population.

Table 1: Bacterial Population (x $10^{6} \mathrm{cfu} \mathrm{g}^{-1}$ of soil) as Influenced by Weed Management Practices (2013) 


\begin{tabular}{|c|c|c|c|c|c|c|c|c|c|c|c|}
\hline S. No. & Treatments & $\begin{array}{c}0 \\
\text { DAT }\end{array}$ & $\begin{array}{c}6 \\
\text { DAT }\end{array}$ & $\begin{array}{c}12 \\
\text { DAT }\end{array}$ & $\begin{array}{c}15 \\
\text { DAT }\end{array}$ & $\begin{array}{c}23 \\
\mathrm{DAT}\end{array}$ & $\begin{array}{c}25 \\
\text { DAT }\end{array}$ & $\begin{array}{c}28 \\
\text { DAT }\end{array}$ & $\begin{array}{c}32 \\
\text { DAT }\end{array}$ & $\begin{array}{c}45 \\
\text { DAT }\end{array}$ & $\begin{array}{c}60 \\
\text { DAT }\end{array}$ \\
\hline $\mathrm{T}_{1}$ & Pretilachlor @ $625 \mathrm{~g}$ a.i ha-1 as PE at 3 DAT & 38.5 & 32.6 & 34.6 & 43.4 & 82.6 & 93.6 & 100.5 & 116.3 & 135.2 & 147.1 \\
\hline $\mathrm{T}_{2}$ & Pyrazosulfuron ethyl $@ 20 \mathrm{~g} \mathrm{ai.} \mathrm{ha}^{-1} 3 \mathrm{DAT}$ & 38.5 & 31.5 & 34.6 & 43.9 & 88.5 & 91.5 & 97.7 & 111.5 & 129.6 & 144.0 \\
\hline$T_{3}$ & $\begin{array}{l}\text { Pretilachlor } 6 \%+\text { bensulfuron methyl } 0.6 \% @ 10 \mathrm{~kg} \\
\text { granules ha" }{ }^{-1} \text { as PE at } 3 \text { DAT }\end{array}$ & 38.5 & 30.7 & 35.0 & 39.7 & 84.7 & 89.5 & 98.7 & 113.5 & 129.5 & 143.8 \\
\hline $\mathrm{T}_{4}$ & $\begin{array}{l}\text { Pyrazosulfuron ethyl @ } 20 \mathrm{~g} \text { ai ha-1 at } 3 \text { DAT followed by } \\
\text { manual weeding at } 25 \text { DAT }\end{array}$ & 38.5 & 31.7 & 35.6 & 42.9 & 86.0 & 90.0 & 100.8 & 116.0 & 132.5 & 151.4 \\
\hline $\mathrm{T}_{5}$ & Penoxsulam @ $22.5 \mathrm{~g}$ a.i ha ${ }^{-1}$ as early PoE at $12 \mathrm{DAT}$ & 38.5 & 40.0 & 44.0 & 39.3 & 77.3 & 78.9 & 91.3 & 107.3 & 128.4 & 149.4 \\
\hline$T_{6}$ & Cyhalofop-p-butyl@ $100 \mathrm{~g}$ a. ha $a^{-1}$ as early PoE 12 DAT & 38.5 & 39.4 & 43.6 & 36.0 & 78.4 & 80.5 & 94.1 & 109.8 & 128.6 & 144.5 \\
\hline $\mathrm{T}_{7}$ & Bispyibac sodium @ $25 \mathrm{~g}$ a. ha $a^{-1}$ as PoE 25 DAT & 38.5 & 41.7 & 44.6 & 56.0 & 83.3 & 89.0 & 83.5 & 92.2 & 117.5 & 143.3 \\
\hline $\mathrm{T}_{8}$ & Azimsulfuron @ $35 \mathrm{~g}$ a. ha $a^{-1}$ as $\mathrm{P}_{0} \mathrm{E}$ at $25 \mathrm{DAT}$ & 38.5 & 40.2 & 46.0 & 53.0 & 85.0 & 93.8 & 85.2 & 95.7 & 114.2 & 141.2 \\
\hline$T_{9}$ & $\begin{array}{l}\text { Bispyibac sodium @ } 25 \mathrm{~g} \text { a. ha hal }{ }^{-1} \text { ethoxysulfuron } \\
18.75 \mathrm{~g} \text { a.i ha- as PoE at } 25 \mathrm{DAT}\end{array}$ & 38.5 & 41.0 & 46.6 & 53.1 & 83.5 & 91.8 & 83.2 & 91.7 & 117.1 & 147.9 \\
\hline $\mathrm{T}_{10}$ & $\begin{array}{l}\text { Bispyibac sodium @ } 20 \mathrm{~g} \text { a. ha- } a^{-1}+\text { metsulfuron methyl }+ \\
\text { chlorimuron ethyl @ } 4 \mathrm{~g} \text { a. ha- }{ }^{-1} \text { as PoE at } 25 \text { DAT }\end{array}$ & 38.5 & 39.4 & 46.0 & 53.0 & 84.9 & 93.9 & 84.1 & 96.3 & 118.0 & 141.4 \\
\hline $\mathrm{T}_{11}$ & $\begin{array}{l}\text { Pretilachlor @ } 750 \mathrm{~g} \text { ai ha } \mathrm{h}^{-1} \text { as } \mathrm{PE} \text { at } 3 \mathrm{DAT} \text { followed by } \\
\text { ethoxysulfuron @ } 18.75 \mathrm{~g} \text { a. ha } \mathrm{a}^{-1} \text { as } \mathrm{PoE} \text { at } 25 \mathrm{DAT}\end{array}$ & 38.5 & 30.4 & 36.6 & 44.8 & 84.8 & 93.8 & 87.1 & 98.5 & 119.1 & 142.0 \\
\hline $\mathrm{T}_{12}$ & $\begin{array}{l}\text { Pretilachlor @ } 750 \mathrm{~g} \text { ai ha }{ }^{-1} \text { as PE at } 3 \text { DAT followed by } \\
\text { metsulfuron methyl + chlorimuron ethyl @ } 4 \mathrm{~g} \text { a. ha has as } \\
\text { PoE at } 25 \text { DAT }\end{array}$ & 38.5 & 29.1 & 36.3 & 41.2 & 88.4 & 90.8 & 81.3 & 93.9 & 118.5 & 145.1 \\
\hline $\mathrm{T}_{13}$ & Hand weeding twice at 25 and 45 DAT & 38.5 & 40.6 & 45.0 & 57.6 & 83.3 & 92.6 & 106.4 & 113.2 & 121.1 & 134.0 \\
\hline $\mathrm{T}_{14}$ & Weedy check & 38.5 & 40.8 & 47.0 & 54.2 & 84.2 & 94.3 & 105.9 & 113.7 & 117.8 & 131.6 \\
\hline & SEm \pm & - & 1.3 & 1.3 & 3.5 & 2.1 & 2.4 & 3.0 & 5.1 & 2.9 & 3.1 \\
\hline & $\mathrm{CD}(\mathrm{P}=0.05)$ & - & 3.8 & 3.9 & 10.4 & 6.2 & 6.9 & 8.8 & 15.0 & 8.5 & 9.0 \\
\hline
\end{tabular}

Table 2: Bacterial Population ( $\mathbf{x ~}^{1}{ }^{6} \mathrm{cfu}^{-1}$ of soil) as Influenced by Weed Management Practices (2014)

\begin{tabular}{|c|c|c|c|c|c|c|c|c|c|c|c|}
\hline S. No. & Treatments & $\begin{array}{c}0 \\
\text { DAT }\end{array}$ & $\begin{array}{c}6 \\
\text { DAT }\end{array}$ & $\begin{array}{c}12 \\
\mathrm{DAT}\end{array}$ & $\begin{array}{c}15 \\
\text { DAT }\end{array}$ & $\begin{array}{c}23 \\
\text { DAT }\end{array}$ & $\begin{array}{c}25 \\
\text { DAT }\end{array}$ & $\begin{array}{c}28 \\
\text { DAT }\end{array}$ & $\begin{array}{c}32 \\
\text { DAT }\end{array}$ & $\begin{array}{c}45 \\
\text { DAT }\end{array}$ & $\begin{array}{c}60 \\
\text { DAT }\end{array}$ \\
\hline $\mathrm{T}_{1}$ & Pretilachlor @ 625 g a. hat as PE at 3 DAT & 40.1 & 31.8 & 36.1 & 44.6 & 96.8 & 104.2 & 118.2 & 133.9 & 145.8 & 153.4 \\
\hline $\mathrm{T}_{2}$ & Pyrazosulfuron ethyl @ $20 \mathrm{~g}$ a. ha.'-13 DAT & 40.1 & 32.4 & 36.6 & 48.0 & 94.8 & 100.8 & 116.1 & 128.1 & 144.5 & 148.7 \\
\hline $\mathrm{T}_{3}$ & $\begin{array}{l}\text { Pretilachlor 6\% + bensulfuron methyl } 0.6 \% @ 10 \mathrm{~kg} \\
\text { granules hat as PE at } 3 \mathrm{DAT}\end{array}$ & 40.1 & 30.0 & 34.5 & 44.4 & 92.8 & 100.6 & 114.3 & 134.0 & 145.7 & 150.6 \\
\hline $\mathrm{T}_{4}$ & $\begin{array}{l}\text { Pyrazosulfuron ethyl @ } 20 \mathrm{~g} \text { a. ha.-1 at } 3 \text { DAT followed by } \\
\text { manual weeding at } 25 \mathrm{DAT}\end{array}$ & 40.1 & 33.8 & 37.9 & 47.5 & 93.3 & 104.2 & 114.4 & 132.7 & 147.6 & 152.7 \\
\hline $\mathrm{T}_{5}$ & Penoxsulam @ $22.5 \mathrm{~g}$ a.i ha. ${ }^{-1}$ as early PoE at $12 \mathrm{DAT}$ & 40.1 & 42.7 & 47.1 & 35.5 & 81.2 & 93.9 & 101.0 & 118.9 & 141.1 & 154.9 \\
\hline $\mathrm{I}_{6}$ & Cyhalofop-p-butyl @ $100 \mathrm{~g}$ a.i ha ${ }^{-1}$ as early PoE 12 DAT & 40.1 & 44.4 & 48.4 & 39.2 & 82.5 & 89.5 & 96.7 & 120.5 & 139.5 & 152.4 \\
\hline $\mathrm{T}_{7}$ & Bispyribac sodium @ $25 \mathrm{~g}$ a.i ha ${ }^{-1}$ as PoE 25 DAT & 40.1 & 45.6 & 47. & 58.90 & 92.3 & 101.3 & 89.3 & 101.5 & 124.3 & 147.8 \\
\hline $\mathrm{T}_{8}$ & Azimsulfuron @ $35 \mathrm{~g}$ a. ha $\mathrm{h}^{-1}$ as $\mathrm{PoE}$ at $25 \mathrm{DAT}$ & 40.1 & 46.0 & 47.0 & 59.0 & 96.4 & 106.7 & 82.8 & 106.5 & 129.0 & 146.9 \\
\hline $\mathrm{T}_{9}$ & $\begin{array}{l}\text { Bispyibac sodium @ } 25 \mathrm{~g} \mathrm{ai.} \mathrm{ha-1/}+\text { ethoxysulfuron } \\
18.75 \mathrm{~g} \text { a.i hat as PoE at } 25 \mathrm{DAT}\end{array}$ & 40.1 & 44.1 & 50.2 & 61.0 & 96.0 & 104.3 & 88.5 & 103.7 & 123.7 & 146.9 \\
\hline$T_{10}$ & $\begin{array}{l}\text { Bispyribac sodium @ } 20 \mathrm{~g} \text { a. ha } a^{-1}+\text { metsulfuron methyl }+ \\
\text { chlorimuron ethyl @ } 4 \mathrm{~g} \text { a.i ha }{ }^{-1} \text { as } \mathrm{PoE} \text { at } 25 \mathrm{DAT}\end{array}$ & 40.1 & 42.4 & 44.1 & 59.5 & 98.5 & 105.7 & 81.8 & 100.4 & 128.3 & 135.8 \\
\hline $\mathrm{T}_{11}$ & $\begin{array}{l}\text { Pretilachlor @ } 750 \mathrm{~g} \text { a. ha } a^{-1} \text { as PE at } 3 \text { DAT followed by } \\
\text { ethoxysulfuron @ } 18.75 \mathrm{~g} \text { a. hal as PoE at } 25 \text { DAT }\end{array}$ & 40.1 & 31.0 & 32.6 & 45.0 & 97.0 & 103.3 & 85.9 & 106.0 & 129.0 & 145.7 \\
\hline $\mathrm{T}_{12}$ & $\begin{array}{l}\text { Pretilachlor @ } 750 \mathrm{~g} \text { a.i ha }{ }^{-1} \text { as PE at } 3 \text { DAT followed by } \\
\text { metsulfuron methyl }+ \text { chlorimuron ethyl } @ 4 \mathrm{~g} \text { a.i. had as } \\
\text { PoE at } 25 \text { DAT }\end{array}$ & 40.1 & 31.3 & 32.4 & 46.2 & 94.1 & 104.2 & 80.4 & 98.8 & 123.0 & 143.5 \\
\hline $\mathrm{T}_{13}$ & Hand weeding twice at 25 and 45 DAT & 40.1 & 45.5 & 51.0 & 63.0 & 93.7 & 104.3 & 115.0 & 124.6 & 136.3 & 142.7 \\
\hline $\mathrm{T}_{14}$ & Weedy check & 40.1 & 43.7 & 49.1 & 62.0 & 96.6 & 104.7 & 116.7 & 128.3 & 138.0 & 147.2 \\
\hline & SEm $t$ & - & 2.5 & 2.1 & 1.5 & 1.8 & 2.3 & 1.7 & 3.0 & 2.8 & 6.4 \\
\hline & $\mathrm{CD}(\mathrm{P}=0.05)$ & - & 4.3 & 6.1 & 4.2 & 5.3 & 6.7 & 5.5 & 8.7 & 8.3 & NS \\
\hline
\end{tabular}


Table 3: Fungal Population ( $\mathrm{x} \mathrm{10}^{1} \mathrm{cfu}^{-1}$ of soil) as Influenced by Weed Management Practices (2013)

\begin{tabular}{|c|c|c|c|c|c|c|c|c|c|c|c|}
\hline $\begin{array}{l}\text { S. } \\
\text { No }\end{array}$ & Treatments & $\begin{array}{c}0 \\
\text { DAT }\end{array}$ & $\begin{array}{c}6 \\
\text { DAT }\end{array}$ & $\begin{array}{c}12 \\
\text { DAT }\end{array}$ & $\begin{array}{c}15 \\
\text { DAT }\end{array}$ & $\begin{array}{c}23 \\
\text { DAT }\end{array}$ & $\begin{array}{c}25 \\
\text { DAT }\end{array}$ & $\begin{array}{c}28 \\
\text { DAT }\end{array}$ & $\begin{array}{c}32 \\
\text { DAT }\end{array}$ & $\begin{array}{c}45 \\
\text { DAT }\end{array}$ & $\begin{array}{c}60 \\
\text { DAT }\end{array}$ \\
\hline $\mathrm{T}_{1}$ & Pretilachlor @ $625 \mathrm{~g}$ a.i ha ${ }^{-1}$ as PE at $3 \mathrm{DAT}$ & 9.5 & 6.7 & 9.7 & 12.7 & 16.9 & 24.2 & 25.7 & 30.7 & 31.9 & 33.0 \\
\hline $\mathrm{T}_{2}$ & Pyrazosulfuron ethyl @ $20 \mathrm{~g}$ a.i ha- 3 DAT & 9.5 & 5.9 & 12.0 & 15.2 & 16.7 & 23.4 & 25.0 & 28.0 & 29.0 & 31.3 \\
\hline $\mathrm{T}_{3}$ & $\begin{array}{l}\text { Pretilachlor } 6 \%+\text { bensulfuron methyl } 0.6 \% @ 10 \mathrm{~kg} \\
\text { granules ha" }{ }^{-1} \text { as PE at } 3 \text { DAT }\end{array}$ & 9.5 & 6.7 & 10.7 & 13.9 & 17.0 & 23.5 & 25.3 & 27.7 & 29.6 & 32.3 \\
\hline $\mathrm{T}_{4}$ & $\begin{array}{l}\text { Pyrazosulfuron ethyl @ } 20 \mathrm{~g} \text { a.i ha. }{ }^{-1} \text { at } \\
\text { 3DAT followed by manual weeding at } 25 \text { DAT }\end{array}$ & 9.5 & 5.8 & 13.1 & 16.5 & 19.0 & 23.6 & 25.7 & 28.3 & 29.1 & 32.0 \\
\hline $\mathrm{T}_{5}$ & Penoxsulam @ $22.5 \mathrm{~g}$ a.i hat as PoE at 12 DAT & 9.5 & 10.7 & 17.4 & 8.7 & 12.5 & 16.2 & 20.3 & 27.3 & 29.7 & 31.3 \\
\hline $\mathrm{T}_{6}$ & Cyhalofop-p-butyl @ $100 \mathrm{~g}$ a.i ha-1 as PoE 12DAT & 9.5 & 10.6 & 20.8 & 9.0 & 13.2 & 15.0 & 17.7 & 27.7 & 29.2 & 31.3 \\
\hline $\mathrm{T}_{7}$ & Bispyribac sodium @ $25 \mathrm{~g}$ a.i ha.-1 as PoE 25 DAT & 9.5 & 10.4 & 15.6 & 19.2 & 20.1 & 23.2 & 16.1 & 25.0 & 30.0 & 33.3 \\
\hline $\mathrm{T}_{8}$ & Azimsulfuron @ $35 \mathrm{~g}$ ai ha $a^{-1}$ as PoE at 25 DAT & 9.5 & 10.7 & 17.4 & 21.3 & 21.2 & 23.8 & 15.6 & 24.3 & 28.0 & 32.3 \\
\hline $\mathrm{T}_{9}$ & $\begin{array}{l}\text { Bispyribac sodium @ } 25 \mathrm{~g} \text { a.i ha } a^{-1}+\text { ethoxy } \\
\text { sulfuron } 18.75 \mathrm{~g} \text { a. hat }{ }^{-1} \text { as PoE at } 25 \mathrm{DAT}\end{array}$ & 9.5 & 10.6 & 15.4 & 19.0 & 20.5 & 22.8 & 16.1 & 23.3 & 29.3 & 31.0 \\
\hline$T_{10}$ & $\begin{array}{l}\text { Bispyibac sodium @ } 25 \mathrm{~g} \text { a. ha }{ }^{-1}+\text { metsulfuron } \\
+ \text { chlorimuron ethyl @ } 4 \mathrm{~g} \text { a. ha } a^{-1} \text { as PoE 25DAT }\end{array}$ & 9.5 & 10.6 & 16.0 & 19.7 & 20.7 & 24.3 & 15.6 & 23.7 & 26.9 & 31.0 \\
\hline$T_{11}$ & $\begin{array}{l}\text { Pretilachlor @ } 9750 \mathrm{~g} \text { a. ha }{ }^{-1} \text { as PE } \\
\text { at } 3 \text { DAT followed by ethoxysulfuron @ } \\
18.75 \mathrm{~g} \text { a. ha has as PoE at } 25 \text { DAT }\end{array}$ & 9.5 & 6.3 & 10.6 & 13.8 & 17.1 & 23.7 & 16.0 & 25.3 & 29.3 & 32.3 \\
\hline$T_{12}$ & $\begin{array}{l}\text { Pretilachlor @ } 750 \mathrm{~g} \text { a. ha }{ }^{-1} \text { as PE at } 3 \text { DAT } \\
\text { followed by metsulfuron methyl }+ \text { chlorimuron } \\
\text { ethyl @ } 4 \mathrm{~g} \text { a.iha } a^{-1} \text { as PoE at } 25 \mathrm{DAT}\end{array}$ & 9.5 & 6.4 & 11.3 & 14.5 & 17.1 & 23.8 & 17.0 & 24.0 & 26.7 & 31.0 \\
\hline $\mathrm{T}_{13}$ & Hand weeding twice at 25 and 45 DAT & 9.5 & 10.7 & 16.6 & 20.3 & 20.5 & 23.4 & 25.3 & 30.0 & 30.0 & 32.0 \\
\hline $\mathrm{T}_{14}$ & weedy check & 9.5 & 10.5 & 17.5 & 21.4 & 22.0 & 24.2 & 25.3 & 28.3 & 29.1 & 32.3 \\
\hline & SEm+ & - & 0.2 & 1.8 & 0.8 & 1.8 & 0.7 & 1.4 & 1.1 & 0.9 & 0.5 \\
\hline & $\mathrm{CD}(\mathrm{P}=0.05)$ & - & 0.6 & 5.3 & 2.4 & 5.4 & 2.0 & 4.2 & 3.1 & 2.5 & 1.5 \\
\hline
\end{tabular}

Table 4: Fungal Population (x $10^{1} \mathrm{cfu} \mathrm{g}^{-1}$ of Soil) as Influenced by Weed Management Practices (2014)

\begin{tabular}{|c|c|c|c|c|c|c|c|c|c|c|c|}
\hline $\begin{array}{l}\text { S. } \\
\text { No }\end{array}$ & Treatments & $\begin{array}{c}0 \\
\text { DAT }\end{array}$ & $\begin{array}{c}6 \\
\text { DAT }\end{array}$ & $\begin{array}{c}12 \\
\text { DAT }\end{array}$ & $\begin{array}{c}15 \\
\text { DAT }\end{array}$ & $\begin{array}{c}23 \\
\text { DAT }\end{array}$ & $\begin{array}{c}25 \\
\text { DAT }\end{array}$ & $\begin{array}{c}28 \\
\text { DAT }\end{array}$ & $\begin{array}{c}32 \\
\text { DAT }\end{array}$ & $\begin{array}{c}45 \\
\text { DAT }\end{array}$ & $\begin{array}{c}60 \\
\text { DAT }\end{array}$ \\
\hline $\mathrm{T}_{1}$ & Pretilachlor $@ 625 \mathrm{~g}$ a.i ha ${ }^{-1}$ as PE at 3 DAT & 8.9 & 7.4 & 9.3 & 16.0 & 22.3 & 29.4 & 30.0 & 32.0 & 33.7 & 35.0 \\
\hline $\mathrm{T}_{2}$ & Pyrazosulfuron ethyl @ $20 \mathrm{~g}$ a.i ha- 3 DAT & 8.9 & 7.4 & 10.6 & 18.9 & 22.9 & 26.0 & 28.3 & 30.3 & 31.8 & 33.7 \\
\hline $\mathrm{T}_{3}$ & $\begin{array}{l}\text { Pretilachlor } 6 \%+\text { bensulfuron methyl } 0.6 \% @ 10 \mathrm{~kg} \\
\text { granules ha-1 as PE at } 3 \text { DAT }\end{array}$ & 8.9 & 7.5 & 9.7 & 17.2 & 22.5 & 29.5 & 30.3 & 32.0 & 33.7 & 35.3 \\
\hline $\mathrm{T}_{4}$ & $\begin{array}{l}\text { Pyrazosulfuron ethyl @ } 20 \mathrm{~g} \text { a. h ha.-1 at } \\
\text { 3DAT followed by manual weeding at } 25 \text { DAT }\end{array}$ & 8.9 & 7.9 & 11.5 & 20.3 & 23.3 & 29.7 & 30.3 & 32.3 & 33.8 & 34.0 \\
\hline $\mathrm{T}_{5}$ & Penoxsulam $@ 22.5 \mathrm{~g}$ a.i ha- ${ }^{-1}$ as PoE at $12 \mathrm{DAT}$ & 8.9 & 10.7 & 16.8 & 9.4 & 10.8 & 20.4 & 22.7 & 28.0 & 31.3 & 33.0 \\
\hline $\mathrm{T}_{6}$ & Cyhalofop-p-butyl @ $100 \mathrm{~g}$ a.i ha $a^{-1}$ as PoE 12DAT & 8.9 & 10.7 & 18.3 & 8.2 & 9.4 & 18.9 & 22.0 & 28.3 & 31.0 & 33.0 \\
\hline $\mathrm{T}_{7}$ & Bispyribac sodium @ $25 \mathrm{~g}$ a.i ha- ${ }^{-1}$ as PoE 25 DAT & 8.9 & 10.5 & 16.2 & 23.5 & 26.9 & 29.2 & 17.0 & 24.3 & 28.3 & 33.3 \\
\hline $\mathrm{T}_{8}$ & Azimsulfuron $@ 35 \mathrm{~g} \mathrm{ai} \mathrm{ha} a^{-1}$ as PoE at 25 DAT & 8.9 & 10.7 & 18.2 & 25.9 & 29.7 & 30.0 & 17.0 & 25.7 & 27.0 & 32.7 \\
\hline $\mathrm{T}_{9}$ & $\begin{array}{l}\text { Bispyribac sodium @ } 25 \mathrm{~g} \text { a. ha- }{ }^{-1+} \text { ethoxy } \\
\text { sulfuron } 18.75 \mathrm{~g} \text { a. } \mathrm{h}^{-1} \text { as PoE at } 25 \mathrm{DAT}\end{array}$ & 8.9 & 10.7 & 17.1 & 23.2 & 26.6 & 28.7 & 16.7 & 25.0 & 27.7 & 30.0 \\
\hline $\mathrm{T}_{10}$ & $\begin{array}{l}\text { Bispyribac sodium @ } 25 \mathrm{~g} \text { a.i ha-1 }+ \text { metsulfuron } \\
\text { + chlorimuron ethyl @ } 4 \mathrm{~g} \text { a.i ha- }{ }^{-1} \text { as PoE 25DAT }\end{array}$ & 8.9 & 10.7 & 17.7 & 24.1 & 27.6 & 30.6 & 17.0 & 23.0 & 26.3 & 32.0 \\
\hline $\mathrm{T}_{11}$ & $\begin{array}{l}\text { Pretilachlor @ } 950 \mathrm{~g} \text { a. ha }{ }^{-1} \text { as PE } \\
\text { at } 3 \text { DAT followed by ethoxysulfuron @ } \\
18.75 \mathrm{~g} \text { a.i ha }{ }^{-1} \text { as PoE at } 25 \text { DAT }\end{array}$ & 8.9 & 7.0 & 10.0 & 17.2 & 20.9 & 29.8 & 17.7 & 23.7 & 26.2 & 32.0 \\
\hline $\mathrm{T}_{12}$ & $\begin{array}{l}\text { Pretilachlor @ } 750 \mathrm{~g} \text { a. ha } a^{-1} \text { as PE at } 3 \text { DAT followed } \\
\text { by metsulfuron methyl + chlorimuron ethyl @ } 4 \mathrm{~g} \\
\text { a.iha- }{ }^{-1} \text { as PoE at } 25 \text { DAT }\end{array}$ & 8.9 & 7.3 & 10.1 & 18.0 & 21.9 & 30.0 & 17.3 & 23.0 & 27.0 & 35.0 \\
\hline $\mathrm{T}_{13}$ & Hand weeding twice at 25 and 45 DAT & 8.9 & 10.6 & 18.2 & 24.8 & 28.4 & 30.5 & 31.0 & 28.7 & 31.3 & 33.3 \\
\hline $\mathrm{T}_{14}$ & weedy check & 8.9 & 10.6 & 19.2 & 25.9 & 28.7 & 29.4 & 31.0 & 32.7 & 34.6 & 36.0 \\
\hline & $\mathrm{SEm}+$ & - & 0.3 & 1.1 & 0.5 & 2.2 & 1.7 & 0.9 & 1.4 & 1.2 & 1.1 \\
\hline & $\mathrm{CD}(\overline{\mathrm{P}}=0.05)$ & - & 0.9 & 3.1 & 1.4 & 6.3 & 4.8 & 2.7 & 4.2 & 3.6 & N.S. \\
\hline
\end{tabular}


Table 5: Actinomycetes Population (x 10 $\mathrm{cfu}^{-1}$ of Soil) as Influenced by Weed Management Practices (2013)

\begin{tabular}{|c|c|c|c|c|c|c|c|c|c|c|c|}
\hline S. No & Treatments & $\begin{array}{c}0 \\
\text { DAT }\end{array}$ & $\begin{array}{c}6 \\
\text { DAT }\end{array}$ & $\begin{array}{c}12 \\
\text { DAT }\end{array}$ & $\begin{array}{c}15 \\
\text { DAT }\end{array}$ & $\begin{array}{c}23 \\
\text { DAT }\end{array}$ & $\begin{array}{c}25 \\
\text { DAT }\end{array}$ & $\begin{array}{c}28 \\
\text { DAT }\end{array}$ & $\begin{array}{c}32 \\
\text { DAT }\end{array}$ & $\begin{array}{c}45 \\
\text { DAT }\end{array}$ & $\begin{array}{c}60 \\
\text { DAT }\end{array}$ \\
\hline $\mathrm{T}_{1}$ & Pretilachlor @ 625 g a.i ha ${ }^{-1}$ as PE at 3 DAT & 29.4 & 28.7 & 32.0 & 43.2 & 48.6 & 51.2 & 55.0 & 62.7 & 69.8 & 76.8 \\
\hline $\mathrm{T}_{2}$ & Pyrazosulfuron ethyl @20 g a.i ha ${ }^{-1} 3$ DAT & 29.4 & 27.5 & 33.0 & 44.1 & 47.7 & 49.6 & 52.0 & 60.8 & 64.4 & 70.7 \\
\hline $\mathrm{T}_{3}$ & $\begin{array}{l}\text { Pretilachlor } 6 \%+\text { bensulfuron methyl } 0.6 \% @ \\
10 \mathrm{~kg} \text { granules ha }{ }^{-1} \text { as } \mathrm{PE} \text { at } 3 \mathrm{DAT}\end{array}$ & 29.4 & 27.4 & 30.5 & 45.6 & 46.8 & 51.2 & 54.0 & 61.6 & 67.0 & 74.5 \\
\hline $\mathrm{T}_{4}$ & $\begin{array}{l}\text { Pyrazosulfuron ethyl @ } 20 \mathrm{~g} \text { a.i ha } \mathrm{a}^{-1} \text { at } \\
\text { 3DAT followed by manual weeding at } 25 \text { DAT }\end{array}$ & 29.4 & 28.8 & 34.9 & 48.4 & 49.7 & 53.4 & 56.0 & 65.9 & 72.0 & 75.8 \\
\hline $\mathrm{T}_{5}$ & Penoxsulam @ 22.5 g a.i ha. ${ }^{-1}$ as PoE at 12 DAT & 29.4 & 28.2 & 35.6 & 33.4 & 39.2 & 43.2 & 52.0 & 61.1 & 64.0 & 76.3 \\
\hline $\mathrm{T}_{6}$ & $\begin{array}{l}\text { Cyhalofop-p-butyl @ } 100 \mathrm{~g} \text { a.i ha }{ }^{-1} \text { as PoE } \\
\text { 12DAT }\end{array}$ & 29.4 & 32.9 & 37.7 & 36.5 & 37.9 & 42.6 & 53.0 & 60.1 & 70.0 & 78.3 \\
\hline $\mathrm{T}_{7}$ & $\begin{array}{l}\text { Bispyribac sodium @ } 25 \mathrm{~g} \text { a.i ha } a^{-1} \text { as PoE } 25 \\
\text { DAT }\end{array}$ & 29.4 & 29.1 & 34.8 & 38.3 & 44.1 & 49.6 & 40.0 & 48.7 & 54.0 & 70.3 \\
\hline $\mathrm{T}_{8}$ & Azimsulfuron @ $35 \mathrm{~g}$ a.i ha- ${ }^{-1}$ as $\mathrm{PoE}$ at $25 \mathrm{DAT}$ & 29.4 & 29.4 & 36.9 & 39.6 & 44.4 & 49.3 & 45.0 & 44.0 & 57.0 & 71.6 \\
\hline $\mathrm{T}_{9}$ & $\begin{array}{l}\text { Bispyribac sodium @ } 25 \mathrm{~g} \text { a.i ha- }{ }^{-1}+\text { ethoxy } \\
\text { sulfuron } 18.75 \mathrm{~g} \text { a.i ha- }{ }^{-1} \text { as PoE at } 25 \text { DAT }\end{array}$ & 29.4 & 33.9 & 35.8 & 41.5 & 48.9 & 52.4 & 50.0 & 47.6 & 58.0 & 78.9 \\
\hline $\mathrm{T}_{10}$ & $\begin{array}{l}\text { Bispyribac sodium @ } 25 \mathrm{~g} \text { a.i ha }{ }^{-1}+ \\
\text { metsulfuron } \\
\text { + chlorimuron ethyl @ } 4 \text { g a.i ha }{ }^{-1} \text { as PoE } \\
\text { 25DAT }\end{array}$ & 29.4 & 31.1 & 37.5 & 44.7 & 46.1 & 49.5 & 48.0 & 49.0 & 55.0 & 74.1 \\
\hline $\mathrm{T}_{11}$ & $\begin{array}{l}\text { Pretilachlor @ } 750 \mathrm{~g} \text { a. } \text { ha }^{-1} \text { as PE } \\
\text { at } 3 \text { DAT followed by ethoxysulfuron @ } \\
18.75 \mathrm{~g} \mathrm{a.i} \mathrm{ha-1} \text { as PoE at } 25 \mathrm{DAT}\end{array}$ & 29.4 & 24.5 & 29.5 & 42.3 & 46.1 & 49.0 & 47.0 & 48.2 & 59.0 & 70.1 \\
\hline $\mathrm{T}_{12}$ & $\begin{array}{l}\text { Pretilachlor @ } 750 \mathrm{~g} \text { a.i ha }{ }^{-1} \text { as PE at } 3 \text { DAT } \\
\text { followed by metsulfuron methyl + chlorimuron } \\
\text { ethyl @ } 4 \mathrm{~g} \text { a.iha-1 as PoE at } 25 \mathrm{DAT}\end{array}$ & 29.4 & 24.9 & 31.4 & 46.1 & 49.5 & 51.3 & 49.0 & 50.4 & 56.0 & 73.9 \\
\hline $\mathrm{T}_{13}$ & Hand weeding twice at 25 and 45 DAT & 29.4 & 34.9 & 38.6 & 41.7 & 49.9 & 53.7 & 53.9 & 55.6 & 60.0 & 68.1 \\
\hline $\mathrm{T}_{14}$ & Weedy check & 29.4 & 33.9 & 36.8 & 45.3 & 48.9 & 52.5 & 55.2 & 59.1 & 64.0 & 67.9 \\
\hline & SEm \pm & - & 3.0 & 2.1 & 3.9 & 2.9 & 2.6 & 2.4 & 1.8 & 3.7 & 4.9 \\
\hline & $\mathrm{CD}(\overline{\mathrm{P}}=0.05)$ & - & 8.8 & 6.2 & 11.2 & 8.1 & 7.6 & 7.1 & 5.3 & 8.9 & 11.6 \\
\hline
\end{tabular}

Table 6: Actinomycetes Population (x $10^{3} \mathrm{cfu}^{-1}$ of soil) as Influenced by Weed Management Practices (2014)

\begin{tabular}{|c|c|c|c|c|c|c|c|c|c|c|c|}
\hline $\begin{array}{l}\text { S. } \\
\text { No }\end{array}$ & Treatments & $\begin{array}{c}0 \\
\text { DAT }\end{array}$ & $\begin{array}{c}6 \\
\text { DAT }\end{array}$ & $\begin{array}{c}12 \\
\text { DAT }\end{array}$ & $\begin{array}{c}15 \\
\text { DAT }\end{array}$ & $\begin{array}{c}23 \\
\text { DAT }\end{array}$ & $\begin{array}{c}25 \\
\text { DAT }\end{array}$ & $\begin{array}{c}28 \\
\text { DAT }\end{array}$ & $\begin{array}{c}32 \\
\text { DAT }\end{array}$ & $\begin{array}{c}45 \\
\text { DAT }\end{array}$ & $\begin{array}{c}60 \\
\text { DAT }\end{array}$ \\
\hline $\mathrm{T}_{1}$ & $\begin{array}{l}\text { Pretilachlor@625 g a.i ha }{ }^{-1} \text { as PE at } 3 \\
\text { DAT }\end{array}$ & 22.9 & 23.3 & 31.6 & 50.3 & 56.1 & 62.3 & 65.1 & 78.0 & 82.3 & 86.7 \\
\hline $\mathrm{T}_{2}$ & $\begin{array}{l}\text { Pyrazosulfuron ethyl@20 g a.i ha }{ }^{-1} 3 \\
\text { DAT }\end{array}$ & 22.9 & 22.0 & 34.2 & 49.4 & 55.5 & 66.5 & 68.6 & 80.9 & 84.0 & 88.2 \\
\hline $\mathrm{T}_{3}$ & $\begin{array}{l}\text { Pretilachlor } 6 \%+\text { bensulfuron methyl } \\
0.6 \% @ 10 \mathrm{~kg} \text { granules ha }{ }^{-1} \text { as PE at } 3 \\
\text { DAT }\end{array}$ & 22.9 & 26.9 & 33.9 & 45.9 & 51.0 & 63.5 & 68.8 & 79.5 & 85.0 & 89.6 \\
\hline $\mathrm{T}_{4}$ & $\begin{array}{l}\text { Pyrazosulfuron ethyl@ } 20 \mathrm{~g} \mathrm{a}^{\mathrm{i} \mathrm{ha}} \mathrm{h}^{-1} \text { at } \\
3 \text { DAT followed by manual weeding at } 25 \\
\text { DAT }\end{array}$ & 22.9 & 25.5 & 35.7 & 46.2 & 55.6 & 64.3 & 69.5 & 79.5 & 86.7 & 91.2 \\
\hline $\mathrm{T}_{5}$ & $\begin{array}{l}\text { Penoxsulam@22.5 g a } \text { i ha }^{-1} \text { as PoE at } 12 \\
\text { DAT }\end{array}$ & 22.9 & 26.1 & 36.7 & 33.5 & 43.3 & 59.9 & 68.7 & 72.5 & 79.5 & 86.7 \\
\hline $\mathrm{T}_{6}$ & $\begin{array}{l}\text { Cyhalofop-p-butyl@100 g a.i ha }{ }^{-1} \text { as PoE } \\
12 \text { DAT }\end{array}$ & 22.9 & 25.5 & 38.7 & 35.5 & 42.6 & 60.4 & 68.1 & 73.3 & 78.6 & 84.9 \\
\hline $\mathrm{T}_{7}$ & $\begin{array}{l}\text { Bispyribac sodium @25 } \mathrm{g} \mathrm{a} . \mathrm{i} \mathrm{ha}^{-1} \text { as PoE } \\
25 \mathrm{DAT}\end{array}$ & 22.9 & 32.2 & 34.2 & 37.9 & 62.2 & 64.3 & 51.7 & 62.9 & 71.6 & 79.7 \\
\hline $\mathrm{T}_{8}$ & $\begin{array}{l}\text { Azimsulfuron@35 g a } . \mathrm{ha}^{-1} \text { as PoE at } 25 \\
\text { DAT }\end{array}$ & 22.9 & 26.9 & 36.4 & 40.7 & 56.9 & 58.3 & 57.3 & 58.2 & 70.5 & 79.3 \\
\hline $\mathrm{T}_{9}$ & $\begin{array}{l}\text { Bispyribacsodium@25 g a.i ha }{ }^{-1}+\text { ethoxy } \\
\text { sulfuron } 18.75 \mathrm{~g} \mathrm{a} . \mathrm{i} \mathrm{ha} \mathrm{g}^{-1} \text { as PoE at } 25 \mathrm{DAT}\end{array}$ & 22.9 & 28.1 & 36.6 & 42.1 & 58.1 & 61.7 & 58.5 & 58.3 & 68.9 & 83.7 \\
\hline $\mathrm{T}_{10}$ & $\begin{array}{l}\text { Bispyribacsodium @25 g a.i ha }{ }^{-1}+ \\
\text { metsulfuron } \\
\text { + chlorimuron ethyl@ } 9 \text { ga.i ha }{ }^{-1} \text { as PoE } \\
25 \text { DAT }\end{array}$ & 22.9 & 27.0 & 38.6 & 43.8 & 57.0 & 60.0 & 58.8 & 58.7 & 69.4 & 80.5 \\
\hline $\mathrm{T}_{11}$ & $\begin{array}{l}\text { Pretilachlor@750 g a.i ha }{ }^{-1} \text { as PE } \\
\text { at } 3 \text { DAT followed by ethoxysulfuron @ } \\
18.75 \mathrm{ga} \text {.i ha }{ }^{-1} \text { as PoE at } 25 \mathrm{DAT}\end{array}$ & 22.9 & 23.9 & 35.2 & 44.0 & 51.6 & 58.7 & 51.3 & 59.7 & 73.1 & 81.9 \\
\hline $\mathrm{T}_{12}$ & $\begin{array}{l}\text { Pretilachlor@750 g a.i ha }{ }^{-1} \text { as PE at } 3 \\
\text { DAT followed by metsulfuronmethyl+ } \\
\text { chlorimuron ethyl @ } 4 \mathrm{~g} \mathrm{a} \text {.iha }^{-1} \text { as PoE at } \\
25 \text { DAT }\end{array}$ & 22.9 & 23.9 & 34.6 & 40.9 & 52.7 & 57.9 & 54.8 & 56.0 & 74.8 & 88.2 \\
\hline $\mathrm{T}_{13}$ & Hand weeding twice at 25 and 45 DAT & 22.9 & 32.6 & 41.5 & 41.0 & 52.6 & 59.8 & 65.0 & 71.3 & 74.9 & 76.4 \\
\hline $\mathrm{T}_{14}$ & Weedy check & 22.9 & 29.3 & 43.0 & 43.4 & 54.6 & 60.7 & 64.4 & 70.7 & 73.9 & 77.5 \\
\hline & SEm \pm & - & 2.4 & 3.5 & 2.3 & 2.3 & 2.6 & 2.6 & 3.1 & 2.8 & 5.8 \\
\hline & $C D(P=0.05)$ & - & 7.0 & 10.1 & 6.8 & 6.6 & 7.5 & 7.6 & 8.8 & 8.3 & 12.1 \\
\hline
\end{tabular}




\section{REFERENCES}

1. Anderson, T.H. 2003. Microbial eco-physiological indicators to assess soil quality, Agriculture, Ecosystems and Environment activities in two soils, Australian Journal of Soil Research. 36 : 449-456.

2. Bera, S. and Ghosh, R.K. 2013. Soil Microflora and Weed Management as Influenced by Atrazine $50 \%$ WP in Sugarcane. Universal Journal of Agricultural Research. 1(2): 41-47.

3. Bowles T.M., Acosta-Martínez, V., Calderón F., Jackson L.E. 2014. Soil enzyme activities, microbial communities, and carbon and nitrogen availability in organic agroecosystems across an intensively-managed agricultural landscape. Soil Biology and Biochemistry. 68: 252-262.

4. Chauhan, A.K., Das, A., Kharkwal, H., Kharkwal, A.C. and Varma, A. 2006. Impact of microorganisms on environment and health. Microbes Health and Environment. 1-12.

5. Corbelt Journall., Askew, S.D., Thomas, W.E. and Wilcut, J.W. 2004. Weed efficacy evaluations for bromaxil, glufosinate, glyphosate, pyrithiobac and sulfosate. Weed Technology. 18: 443-453.

6. Ghosh, R.K., Jana, P., Nongmaithcm, D., Pal, D., Bera, S., Mallick, S., Barman, S. and Kole, R.K. 2012. Prospects of botanical herbicides in system of crop intensification in the Gangetic Inceptisols of India. Proceedings of 6th International Workshop on Software Clones, Hangzhou, China, 17-22: 116-117.

7. Jarvan, M., Edesi, L. Adamson, A. Vosa, T. 2014. Soil microbial communities and dehydrogenase activity depending on farming systems. Plant Soil Environment. $60(10): 459-463$.

8. Johnen, B.G. and Drew, E.A. 1977. Ecological effects of pesticides on soil microorganisms. Journal of Soil Science. 123: $319-$ 324.

9. Nyarko, K. and Datta S. K. D. 1991. A Hand Book for Weed control in Rice. IRRI, Manila, Phillipines. 1-109.

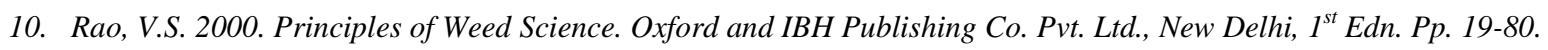

11. Roberts, T. R. 1998. Metabolic Pathways of Agrochemicals: Part 1. Herbicides and Plant Regulators, Royal Society of Chemistry.88-90. 
